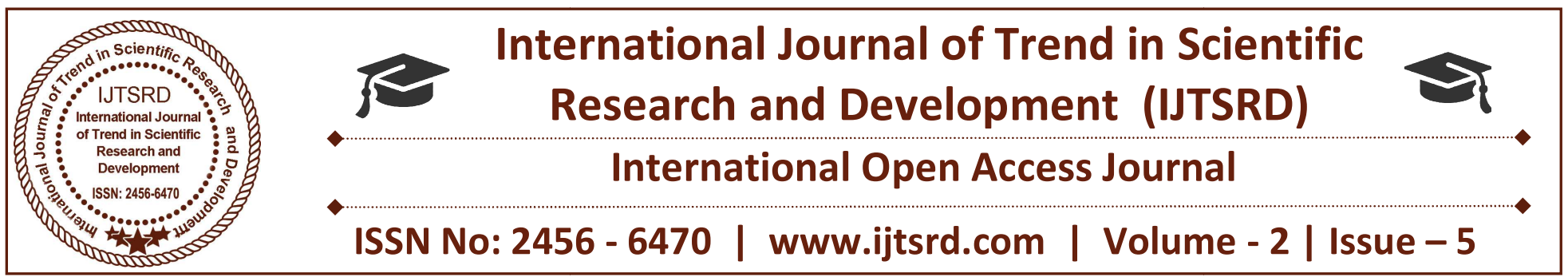

\title{
Experimental Study on Physical Properties of High Strength Concrete With and Without Horse Dung
}

\author{
Akhil Sharma ${ }^{1}$, Prof. Jay Prakash Gupta ${ }^{2}$, Praveen Singh Tomar ${ }^{3}$ \\ PG Student ${ }^{1}$, Guide ${ }^{2}$, Head of Department ${ }^{3}$ \\ Department of Civil Engineering, Patel Institute of Technology, Bhopal, Madhya Pradesh, India
}

\begin{abstract}
Use of fibres is not new to the construction industry. But the way they are being used and its ever-growing varieties have always made it a burning topic for the researchers. The principal reason to incorporate fibres into a cement matrix is to increase the compressive strength and to improve the soundness characteristics of the resultant composite. Previous studies related to the use of natural organic fibres in concrete have shown strength variation with respect to the various types of fibres and fibres content. In the present investigation, an attempt has been made to design a high strength Fibre Reinforced Concrete by proportioning the mix with moisture free pulverized natural organic fibres obtained from horse manure/dung. 11 mixes were prepared separately to determine the characteristics and properties of freshly
\end{abstract} laid concrete. 33 cubes were casted for the determination of compressive strength and 12 beams were casted for the determination of flexural strength of concrete. Later study was carried out on this designed concrete mix by considering different parameters such as fibre content, proportioning of fine aggregates, time (days) and types of tests (Destructive and Non Destructive test). Results of the study have shown that the performance of designed concrete mix with different mix proportions and different percentage of fibres as additive and replacement of fine aggregates are far more efficient and superior to the conventional mix. As the proportion of percentage of fibers is increased, the performance and strength of freshly mixed as well as of hardened concrete cubes gets improved. After increment in percentage of fibers in mixes, a stage comes where the quantity of fibers is well enough to affect the performance as well as strength of concrete cube. This research summarized

the use of horse manure/dung, a natural organic fibre by some percentage in the concrete mix to get favourable workability, compressive and flexural strength.

Keywords: High Strength Concrete, Natural Organic Fibre Reinforced Concrete, Horse Manureldung, Designed Mix, Workability, Flexural Strength, Compressive strength

\section{INTRODUCTION}

\subsection{Concrete}

Concrete is a complex corporeality comprises of aggregate i.e. coarse and fine compressedunitedly with hydrous cement which after desiccation forms a compound stuff. When these collocate aggregate and delicate sand is mixed together with cement and water, the mixture frames easy slurry that is easily poured and molded into precise shape. Oftentimes habituation (such as fibrous) is included in the concoction to amend the physical properties of wet mix. Since aggregates occupy about $60-70 \%$ or more than $70 \%$ of the volume of a concrete mix, they play a significant role on the properties of concrete, including rheological properties of fresh concrete mix, reflex behavior and durability of hardened concrete which directly depends on the presence of C-S-H gel in concrete mass.

\subsection{High Strength Concrete}

High-strength concrete is typically recognized as concrete with a 28-day cylinder compressive strength greater than $35 \mathrm{MPa}$ as per IS code. The deformation characteristic of Normal strength concrete is lesser linear performance than High strength concrete. Many 
a time it may be necessary to estimate the strength of concrete at an early age. One may not be able to stay for 28 days. Many research workers have attempted to estimate the strength of concrete at $1,3,7$, or 14 days and correlate it to 28 days strength. The connection between the strength of concrete at a starting age and 28 days depends upon many factors such as compound composition of cement, fineness of grinding and temperature of curing etc. Moreover mixes with low water cement ratio gains strength, expressed as a percentage of long term strength, more speedily than that of concrete with higher water cement ratio. This is most probably because the cement particles are held at a closer interval in casing to low water cement ratio than that of higher water cement ratio, in which case there is a much better possibility for the formation of continuous Concrete is generally classified as normal strength concrete, High strength concrete and Ultra-high strength concrete. There are no clear cut boundary for the above classification Indian standard recommended methods of mix design denotes the boundary at $35 \mathrm{MPa}$ between Normal Strength Concrete and High Strength Concrete. They did not talk about Ultra High Strength Concrete, but elsewhere in the International discussion, about thirty year ago, the high /strength liable was applied to concrete having strength above $40 \mathrm{MPa}$. More recently, the sill rise to 50 to $60 \mathrm{MPa}$.

\subsection{Fiber Reinforced Concrete}

Random oriented fiber reinforced concrete is one of the most promising composites used in the construction. Usually, for the structural applications steel fibers should be used in a role supplementary to the reinforcing bars. Steel fibers relatively inhibit cracking and improve resistance to material deterioration as a result of fatigue, impact and shrinkage. In applications where the existence of continuous reinforcement is not necessary to the safety and integrity of the structure (e.g., pavements overlays and shotcrete linings), the improvements in flexural strength, impact resistance, and fatigue performance associated with the fibers can be used to reduce section and to enhance performance or both. Some full-scale tests have shown that steel fibers are effective in supplementing or replacing the stirrups in the beams. unit volume than larger diameter fibers. Therefore, for a given fiber length, higher aspect ratio is more beneficial. Most mixes used in practice employ fibers with an aspect ratio less than 100, and failure of composites, therefore is, due primarily to fiber pullout. On the other hand, increased resistance to insert without increasing the aspect ratio is achieved in fibers with deformed surface or end anchorage, failure may involve fracture of some of the fibers, but it is still usually governed by pullout.

\subsection{Natural Organic Fiber}

Perhaps the most common and one of the oldest in use of all the organic continuous reinforcing materials in Portland cement concrete is bamboo. It has largest percentage of fibres which is high in tensile strength and it also has very good strength to weight ratio. Bamboo wastes as well as specially harvested plants have been used as concrete reinforcement in many developing, tropical and sub tropical countries. Bamboo is generally used with low modulus concrete and requires special provision for the end encourage. It is recommended that bamboo main reinforcement in Portland cement concrete should be in range between $3.5 \%$ and $4.5 \%$. Under the serviceability loads the reinforcement strains are then relatively small, and there is a large safety factor between the rupture and the serviceability loads. The main weakness of bamboo, as indeed of any organic material, is its high water absorption potential, which ultimately leads to swelling and shrinkage. Yet another handicap of bamboo reinforcement is its relative fast rate of decay in concrete. To overcome the problems influencing long term durability, bamboo is often pre-treated, initially using sand blasting to remove outer skin, with subsequent soaking in liquid sulphur. To prevent insect attacks, bamboo reinforcement can also be soaked in diesel oil. Field test indicated that over period of up to 10 years in service, durability of bamboo reinforced concrete subjected to a mild environment exposure is usually not a significant problem. Most organic fibers, including wastes, are used as concrete reinforcement. These can be broadly classified as natural, which can be either of vegetable or animal origin or synthetic. Most natural and even synthetic fibre of organic origin has relatively low modulus of elasticity. The most common use for these fibers is to restrain plastic shrinkage, thermal and creep induced cracking. In hardened, structural Portland cement concrete the strain in this fiber are usually too big to effectively control dry shrinkage, thermal and creep induced cracking.

\subsection{Effects of Fiber on Concrete}

The quantity of the fibers added to a cement concrete mixture is measured as a $\%$ of the total volume of the composite (concrete and fibers) termed volume fraction (Vf). Vf typically ranges from 0.1 to $3 \%$. 
Aspect ratio $(1 / \mathrm{d})$ is calculated by dividing fiber length (1) by its diameter (d). Fibers with a non-circular cross section use an equivalent diameter for the calculation of aspect ratio. If the modulus of elasticity of the fiber is higher than the matrix (concrete or mortar binder), they help to carry the load by increasing the tensile strength of the material. Increase in the aspect ratio of the fiber usually segments the flexural strength and toughness of the matrix. However, fibers which are too long tend to ball in the mix and create workability problems. Some recent research indicated that using fibers in concrete has limited effect on the impact resistance of concrete materials.

\subsection{Utilization of Concrete for effective Waste Disposal}

Concrete under broad definition of this term, can be an excellent material for the encapsulation of hazardous wastes. Fundamentally, two types of encapsulation are possible. One is a condensed waste storage for those wastes, which can later re-processed and recycled and second is dispersed waste disposal system, in which low concentration of hazardous waste does not produce harmful effects in the encapsulating concrete which therefore can be used as building and construction material. The composition of Portland cement concrete can be optimized using mineral and chemical admixtures, which in themselves can be waste products, for the encapsulation of each particular hazardous waste. However, the best results in most cases can be obtained with concretes based on hydraulic cements other than Portland, or on the organic cements and sometimes with concrete based on the hybrid of two of the above types. Slag alkaline cements, geo polymer and silica water absorption suspension binder can be particularly effective for long term immobilization of hazardous waste in concrete.

\subsubsection{Horse Manure/Dung}

In this research, natural organic fiber from waste (horse manure) is used as admixture in concrete. The physical composition of horse manure consists of straw, straw pellets, straw flax, flax, wood pellets, saw dust. The chemical composition of the excreta is $24.63 \%$ crude fiber, $32.84 \%$ dry matter, $81.83 \%$ volatile organic matter, $18.17 \%$ ash and $2.95 \%$ ether extract. The fibrous amount in the manure would be higher of such horses whose diet content having green grasses, plant hay (rice, wheat). The horses does anaerobic digestion so their compost, after receiving moisture free doesn't smell bad as compare to other animals excrete. The explanation behind this is size of stomach of horses which are comparatively small than other animals. So the duration of food to remain in their stomach is very less which helps in protecting their manure somehow from biological effects from other animals. Horse manure is alternative source of paper making in paper industry as it is waste material. It is eco friendly, as it doesn't have any bad environmental effect. . The regular fiber length of the manure is $10-15 \mathrm{~mm}$. The fiber has a diameter of $0.1-$ $0.3 \mathrm{~mm}$. About 5.56 Megatons of manure is produced annually in India.

\subsection{Objective of the Study}

As this study can be done in many ways and with many parameters, but according to further clear objectives are as follows:

1. To compare the effect of using horse manure as a coarse aggregate in concrete by partial replacement of sand.

2. To compare the effect of using horse manure as an additive in concrete by partially addingit as the weight of cement.

3. To make the comparative study of properties of concrete with the parameter likefiber content.

\section{LITERATURE REVIEW}

\section{1. "Wastepaper Fibers in Cementitious} Composites" by Craig O. Thomas, Robert C. Thomas and Kenneth C. Hover(1987)

The use of cellulose fibers, reclaimed from waste water from paper recycling, as reinforcement in cementitious building products was discussed. An experimental program was based on the development of a material composed of Portland cement mixed with sludge produced by the treatment of wastewater from a paper recycling plant. This sludge was composed primarily of cellulose fibers and Kaolinite clay. The primary obstacle in the development of a mixing process was the problem of achieving an intimate mixing of the fibers and the cement, as the fibers tend to coalesce and form soft inclusions in the hardened mass. This problem was overcome by introducing the cement in to the sludge prior to chemical or mechanical dewatering, followed by vibratory and pressure dewatering of the cement/sludge slurry. Optical and electron microscope photographs clearly indicated the differences between mixing techniques. Physical properties of the resulting mass were measured as a function of varying mix proportions and mixing techniques. Compressive strength on the order of $10.3 \mathrm{MPa}(1,500 \mathrm{psi})$ and 
tensile strength on the order of $2.8 \mathrm{MPa}$ (400 psi) have been obtained.

\section{2. "Characteristics of concrete reinforced with} San fibers" by Siddique R.(1996)

He compared experimental results of the mechanical properties of the San Fiber reinforced concrete to the theoretical model developed by Pakotiprapha et al. Comparison of the theoretical and experimental results showed good agreement. The aim was to determine the physical and mechanical properties of natural San (CrotolariaJuncea) fibre and its effect on compressive strength, splitting tensile strength and flexural strength (modulus of rupture) of concrete by experimental investigation. The parameters of this work was Concrete mixtures were prepared with three volume fractions of San fibers viz. $0.25 \%, 0.50 \%$, $0.75 \%$, and three fiber lengths viz. $20 \mathrm{~mm}, 25 \mathrm{~mm}, 30$ $\mathrm{mm}$.

3. "Toughness Characteristics of ArengaPinnata Fibre Concrete" by H. Abdul Razakand T. Ferdiansyah(2004)

They concluded that addition of ArengaPinnata fibre increased the toughness characteristic of concrete, the positive effects of the fibre become less significant after 28 days, but still sufficient to give the concrete better toughness properties compared to the plain concrete. This is due to reaction of the fibers with the alkaline pore water in the cement matrix. The study results an examination on the toughness characteristics of the cement concrete containing Arengapinnata fibre. The parameters used in this specific study were 3 fibre lengths of $15 \mathrm{~mm}, 25 \mathrm{~mm}$, and $35 \mathrm{~mm}$ used in two volume portions, i.e., $0.6 \%$ and $0.8 \%$. The values of toughness index, first crack deflection, first crack toughness, toughness indices, and residual strength factors were presented for ages up to around 180 days.

\section{4. "A Review on Pineapple Leaf Fibers, Sisal} Fibers and their Biocomposites" by Supriya Mishra, Amar K Mohanty, Lawrence T Drazal, Manjusri Mishra and Georg Hinrichsen(2004)

The review article is concerned with the structure, composition and properties of PALF and sisal, the chemical modifications of these fibers and pineapple leaf fibre reinforced thermo-sets, thermoplastics, cement, hybrids, rubber and bio-composites. The use of lingo-cellulosic fibers, pineapple leaf fiber (PALF) and sisal as reinforcements in thermoplastic and thermosetting resins for developing low cost and light-weight composites is an emerging field of research in the field of polymer science and technology. While, these bio-fibers have numerous advantages, such as low densities, low cost, nonabrasive nature, low energy consumption, high specific properties, high filling level possible, biodegradability, etc., over synthetic fibers, the absorption of moisture by untreated bio-fibers, poor wetting-ability and insufficient adhesion between the polymer matrix and fiber deteriorate the mechanical properties of composites made up of these bio-fibers. Therefore, the modification of these fibers is a key area of research at present to obtain optimum fibermatrix properties in the mix.

\section{5. "Compressive and Flexural Properties of Hemp Fibre Reinforced Concrete" by Zhijian Li Lijing Wang and Xungai Wang (2006)}

The compressive strength and flexural strength properties of hemp fiber reinforced concretes (FRC) were examined in this research paper. Natural hemp fiber was mixed. They concluded that by using hemp fiber reinforced concrete beneath the optimum conditions, compressive strength increased by $4 \%$, flexural strength increased by $9 \%$, flexural toughness increased by approximately $144 \%$, and flexural toughness index increased by around 214\%. Mechanical properties of the FRC were investigated by mixing natural hemp using dry and wet mixing methods to fabricate the FRC. The main factors affecting compressive and flexural properties of the FRC materials were evaluated with an orthogonal test design. Fiber content by weight has the largest effect. The method for casting hemp FRC has been optimized.

6. "A Novel Oil Well Cementing Technology Using Natural Fibers" by M. M. Al. Darbi, N. O. Saeed, L. O. Ajijolaiya and M. R. Islam (2006)

They concluded that the use of human hair, a waste material, in order to replace polymer fibers. Hair waste has been used as a new natural fiber to reinforce mortar and cement and improve their impermeability. The result concerns the effects of human hair fibers on the reduction of shrinkage cracking of mortar. The influence of mix proportions on the plastic shrinkage of human hair fiber reinforced mortar has been studied. The approach selected in this study was based on the factorial design of experiments. The considered parameters are cement/sand ratio, water/cement ratio, 
and human hair fibers content. The results showed that the human hair fibers are effective in reducing the plastic shrinkage cracks area of mortar by a remarkable percentage up to $92 \%$. The aim of the project was to check the damaging effect of plastic shrinkage in cement mortar, and thus the formation of cracks. In the past, the most common research topic has been in the areas of polymer fibers that are expensive and environmentally unacceptable. In the quest of pursuing technologies that are environmentally friendly, inexpensive and innovative. The application for this project concerned was for such industries where the pipeline systems are lined with a protective layer of cement mortar. In petroleum wells, cement slurry is placed in a wellbore to be hardened into an impermeable mass that seals the annulus from fluid flow and protects the casing from corrosion for the life of the well. When uniform linings of neat cement fail in tension, one or more large cracks are formed and the pressurizing fluid or mud easily flows through the cracks.

7. "Chemically and Thermally Treated Vegetable Fibers for Reinforcement of Cement-Based Composites" by M. A. Arsene, A. Okwo, K. Bilba, A. B. O. Soboyeio and $\mid W . O C$. Soboyejo(2007)

They concluded that acid attack generally degraded the strengths, while alkali attack had only a limited effect. Pyrolyzed banana leaves, coconut coir, and coconut sheaths fibers were also tested. The implications of the results were discussed for the development of strong cementitious matrix composites. This paper presents the effects of chemical and thermal treatments on the strength of vegetable fibers that were being considered as reinforcements in cementitious matrix composites for affordable housing. These include vegetable fibers extracted from banana trunks and sugar cane residues. The results suggested that pyrolysis increased the fiber strength, at least by a factor three.

\section{8. "Performance of Slash Pine Fibers in Fiber Cement Products" by J. H. Morton, T. Cooke and S. A. S. Akers (2009)}

They observed High modulus of rupture, high fracture energy (toughness), excellent dimensional stability, and low water absorption by evaluating Cellulosic fibers produced by the kraft pulping process from slash pine trees (Pinuselliottii), softwood from the south-eastern US. Accelerated aging tests were also run and high performance mix designs showed the most strength retention after aging. Recently conducted plant trials with these fibers have confirmed laboratory findings. These fibers are longer and coarser than most wood fibers and have been found to provide many benefits in fiber cement applications due to their high modulus and high fiber strength. The parameters were finely controlled ranging from $0 \%$ to $4 \%$. Laboratory preparations of multiple formulations of fiber cement products have been carried out incorporating these fibers.

\section{III.METHODOLOGY \& MATERIALS USED}

\section{METHODOLOGY}

\subsection{Experiment Background}

In order to analyze the strength of concrete, the concrete is formed as plain and fibre reinforced concrete molded as cube of side $150 \mathrm{~mm}$ and beam of size $(700 \times 150 \times 150) \mathrm{mm}$. The load is applied on the cube block under universal testing machine for compressive strength and 3 point loading on beam for flexural strength, which causes crack or fracture developed on the surface of cube. For this a proper maintained proportion of fiber is used to attain various data. Using this maintained proportion of fibers, the behavior of fresh concrete is also determined.

\subsection{Mix Design of High Strength Concrete}

Mix design can be defined as the procedure of selecting appropriate ingredients of concrete and determining their virtual proportions with the objective of producing concrete of certain minimum strength and durability as economically as possible. The purpose of designing as can be seen from the above definition is twofold. The primary objective is to achieve the stipulated target strength and durability. The subsequent objective is to make the concrete most economical. Cost wise all concretes depend primarily on two factors; namely cost of material and labor cost, by way of formworks, batching, mixing, transporting and curing is nearly same for high-quality concrete and low quality concrete. Therefore attention is mainly directed to the cost of materials. Since the cost of cement is many times more than the cost of other ingredients, attention is mainly directed to the use of as little cement as possible consistent with strength and durability.

\subsection{Concept used for Concrete Mix Design}

It will be important to recall at this stage the relationship between aggregates and paste which are the two essential ingredients of concrete. Workability 
of the mass is provided by the lubricating effect of the paste and is influenced by the amount and dilution of paste. The strength of concrete is limited by the strength of paste, since mineral aggregates with rare exception are far than the paste compound. The permeability of concrete is governed by the quality and stability of the paste, since slight amount of water flows through aggregate either under pressure or by capillarity. Further, the prime contribution to drying shrinkage of concrete is that of paste. Since the properties of concrete are governed to a substantial amount by the quality of paste, it is accommodation to consider more closely the structure of the paste. The fresh paste is a deferment, not a solution of cement in water.

\subsection{Materials Used}

\subsubsection{Cement}

Ordinary Portland cement of 53 grade was used.

Table No. 3.1 - Properties of cement used in the study (Source-Specifications given as per the Ultratech cement manufacturing company)

\begin{tabular}{|c|c|c|}
\hline \multicolumn{2}{|c|}{ Physical Properties } & $\begin{array}{c}\text { IS: } \\
12269-1987 \\
\text { Specifications }\end{array}$ \\
\hline \multirow{3}{*}{ Soundness } & $\begin{array}{c}\text { Le Chat Expansion } \\
(\mathrm{mm})\end{array}$ & 0.8 Sea \\
\cline { 2 - 3 } & $\begin{array}{c}\text { Auto Clave Expansion } \\
(\%)\end{array}$ & 0.062 / \\
\hline Fineness (m $\left.{ }^{2} / \mathrm{kg}\right)$ & 330 \\
\hline Standard Consistency (\%) & 30.5 \\
\hline Vicat initial setting time (minutes) & 150 \\
\hline Vicat final setting time (minutes) & 225 \\
\hline Compressive strength 3-days (MPa) & 38 \\
\hline Compressive strength 7-days (MPa) & 47.6 \\
\hline Compressive strength 28-days (MPa) & 63.6 \\
\hline Specific gravity & 3.15 \\
\hline
\end{tabular}

\subsubsection{Aggregates}

The maximum nominal size of coarse aggregate is taken as $20 \mathrm{~mm}$. Aggregates of size 10 to $12 \mathrm{~mm}$ is sought-after for structure having blocked-up reinforcement arrangement. Well graded rounded aggregates or cubical aggregate are very much desirable. The test sample should be of uniform quality at all. Fine aggregate can be natural type or manufactured type. The grading must be uniform throughout the work. The Locally available natural sand with $4.75 \mathrm{~mm}$ maximum size was used as fine aggregates, having specific gravity, fineness modulus bulk density water absorption as given in the table 3.2. The coarse aggregate with $20 \mathrm{~mm}$ maximum size having specific gravity, fineness modulus and bulk density as below (also shown in table 3.2) was used as coarse aggregates. Both fine aggregate and coarse aggregate validating to Indian Standard Specifications IS: $383-1970$

\section{Table No. 3.2 - Properties of Aggregates used in the} Study

\begin{tabular}{|c|c|c|}
\hline $\begin{array}{c}\text { Physical Properties of } \\
\text { Coarse and Fine } \\
\text { Aggregates Physical } \\
\text { tests }\end{array}$ & $\begin{array}{c}\text { Coarse } \\
\text { Aggregates }\end{array}$ & $\begin{array}{c}\text { Fine } \\
\text { Aggregates }\end{array}$ \\
\hline $\begin{array}{c}\text { Specific gravity } \\
\text { Fineness modulus (mm) }\end{array}$ & 2.66 & 2.66 \\
\hline Bulk density $\left(\mathrm{kg} / \mathrm{m}^{3}\right)$ & 1540 & 2.68 \\
\hline Water Absorption $(\%)$ & 0.81 & 0.80 \\
\hline
\end{tabular}

\section{RESULTS}

\subsection{TESTS RESULTS}

\subsubsection{Results of Fresh Concrete}

4.1.2 Slump Cone Tests Results

\section{Table No. 4.1-Tests results of Slump Cone Test}

\begin{tabular}{|c|c|}
\hline Mould & Slump $(\mathbf{m m})$ \\
\hline S1 & 68 \\
\hline S2 & 65 \\
\hline S3 & 63 \\
\hline S4 & 60 \\
\hline S5 & 57 \\
\hline S6 & 54 \\
\hline S7 & 67 \\
\hline S8 & 65 \\
\hline S9 & 64 \\
\hline S10 & 62 \\
\hline S11 & 61 \\
\hline
\end{tabular}

The results of slump tests determines that due to increase in the fiber content, there is a indication of very low water cement ratio and hence value of slump decreases with increase in fibrous contents. This is due to reason that manure is highly porous and somehow viscous material. Thus when the fiber is used as a additive in mix proportions, the value of slump starts decreasing randomly. Also when the fiber is used as a replacement of sand in mix proportions, the value of slump also decreases, but doesn't collapse aimlessly. 
Graph No. 4.1- Variation in Slump values for different mix.

\section{Slump Test Results}

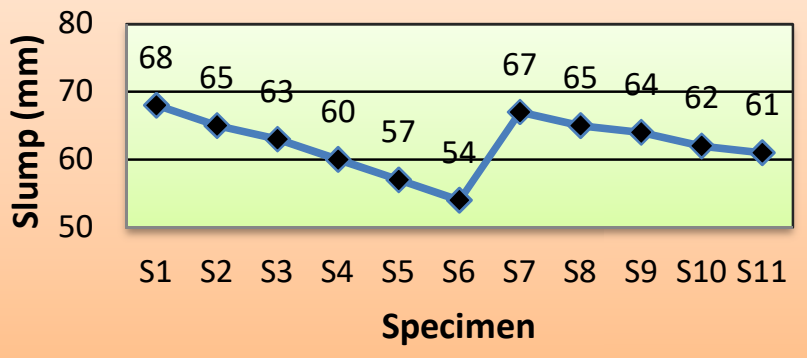

\subsubsection{Compaction Factor Test Results}

Table No. 4.2- Tests Results of Compaction Factor

\begin{tabular}{|c|c|c|c|}
\hline Mix & $\begin{array}{c}\text { Wt. of } \\
\text { Partially } \\
\text { Compacted } \\
\text { Cylinder } \\
\text { (kg.) }\end{array}$ & $\begin{array}{c}\text { Wt. of Fully } \\
\text { Compacted } \\
\text { Cylinder } \\
\text { (kg.) }\end{array}$ & $\begin{array}{c}\text { Compaction } \\
\text { Factor }\end{array}$ \\
\hline CF1 & 31.17 & 33.16 & 0.94 \\
\hline CF2 & 30.86 & 33.19 & 0.93 \\
\hline CF3 & 30.24 & 33.24 & 0.91 \\
\hline CF4 & 29.95 & 33.28 & 0.90 \\
\hline CF5 & 29.32 & 33.32 & 0.88 \\
\hline CF6 & 28.68 & 33.35 & 0.86 \\
\hline CF7 & 30.49 & 33.15 & 0.92 \\
\hline CF8 & 29.81 & 33.13 & 0.90 \\
\hline CF9 & 29.13 & 33.11 & 0.88 \\
\hline CF10 & 28.77 & 33.08 & 0.87 \\
\hline CF11 & 28.10 & 33.06 & 0.85 \\
\hline
\end{tabular}

The result of compaction factor tests also determines the similar behaviour of fresh concrete as in slump test. Due to increase in fiber content, there is a very low water cement ratio because of the porosity of manure which renders the mix to be dry and less water is available for the lubrication of the ingredients of the mix. But also somehow viscous of manure which makes the concrete mix to gain greater bond. Hence the value of compaction factor decreases with increase in fibrous contents in concrete mix and thus workability reduces.
Graph No. 4.2- Variation in Compaction Factor for different mix.

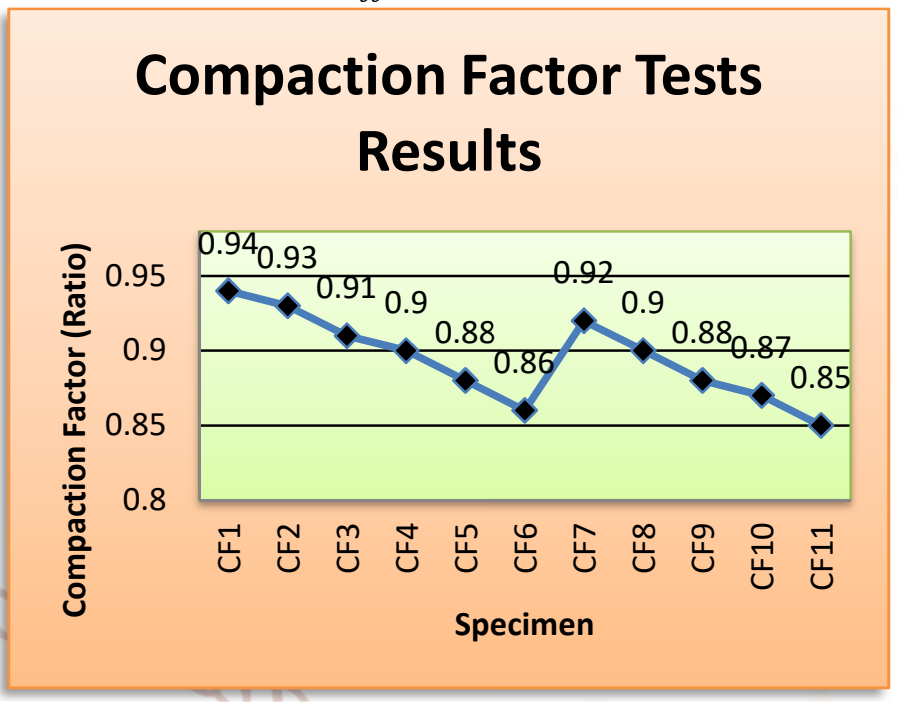

\subsection{Results of Hardened Concrete}

\subsubsection{Compressive Strength Test Results}

The Characteristics Compressive Strength of concrete at 3,7 and 28 days was found in $\mathrm{N} / \mathrm{mm}^{2}$. It was observed that when fibre is used as additive in concrete mix, with increases in fiber content the early age growth of concrete decreases. The reason behind that is due to moisture in concrete due to fiber. But when fiber is used as a replacement of sand, with increase in fibre there is a increase in early age growth. This is due to reason that the greater bonding of fibre amongst them. However, the best results at 28 days was in batch CT4 when (6\%) fibre is used as additive and CT10 when (8\%) fibre is used as a replacement of sand.

Table No. 4.3-Tests results of Compressive Strength Test.

\begin{tabular}{|c|c|c|c|c|c|c|}
\hline \multirow{3}{*}{ Cube } & \multicolumn{6}{|c|}{ Compressive Strength } \\
\hline & \multicolumn{2}{|c|}{ After 3 days } & \multicolumn{2}{|c|}{ After 7 days } & \multicolumn{2}{|c|}{ After 28 days } \\
\hline & $\mathrm{KN}$ & $\mathrm{N} / \mathrm{mm}^{2}$ & $\mathrm{KN}$ & $\mathrm{N} / \mathrm{mm}^{2}$ & KN & $\mathrm{N} / \mathrm{mm}^{2}$ \\
\hline CT1 & 450 & 20.00 & 770 & 34.22 & 1150 & 51.11 \\
\hline CT2 & 490 & 77 & 780 & 00 & 60 & S. \\
\hline CT3 & 485 & .55 & 775 & 4.44 & 90 & 88 \\
\hline CT4 & 490 & 21.77 & 785 & 4.88 & 1225 & 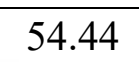 \\
\hline CT5 & 470 & 20.88 & 775 & 4.44 & 1210 & 77 \\
\hline CT6 & 46 & 44 & 750 & 3.33 & 35 & 52.66 \\
\hline CT7 & 450 & 20.00 & 710 & 1.55 & 1155 & 133 \\
\hline CT8 & 460 & 20.44 & 720 & 32.00 & 1185 & 52.66 \\
\hline CT9 & 48 & 21.55 & 755 & 3.55 & 1215 & 54.00 \\
\hline CT10 & 52 & 23.33 & 810 & 36.00 & 1255 & 55.77 \\
\hline CT11 & 490 & 21.77 & 725 & 32.22 & 1190 & 52.88 \\
\hline
\end{tabular}


International Journal of Trend in Scientific Research and Development (IJTSRD) ISSN: 2456-6470

Graph No. 4.3-Variation in Compressive Strength of cubes in 3 days.

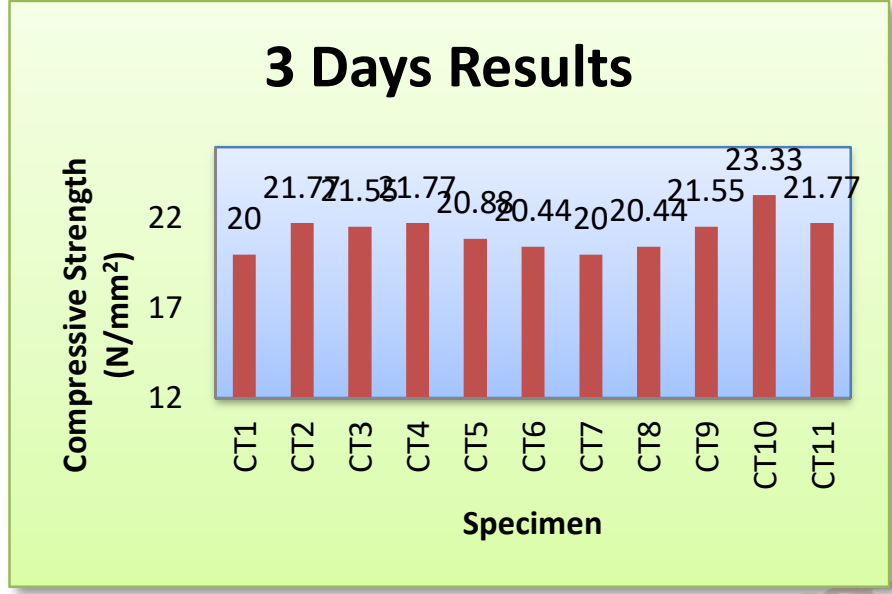

Graph No. 4.4- Variation in Compressive Strength of Cubes in 7 days.

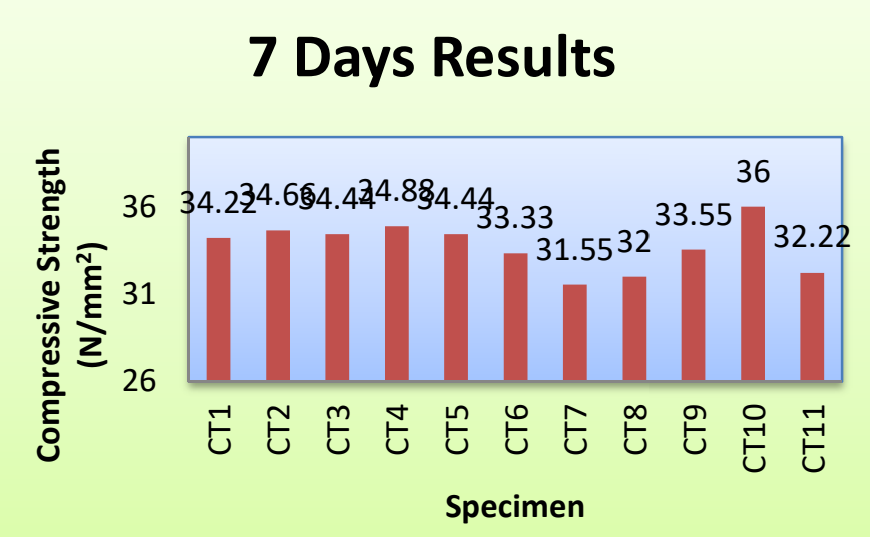

Graph No. 4.5- Variation in Compressive Strength of Cubes in 28 days.

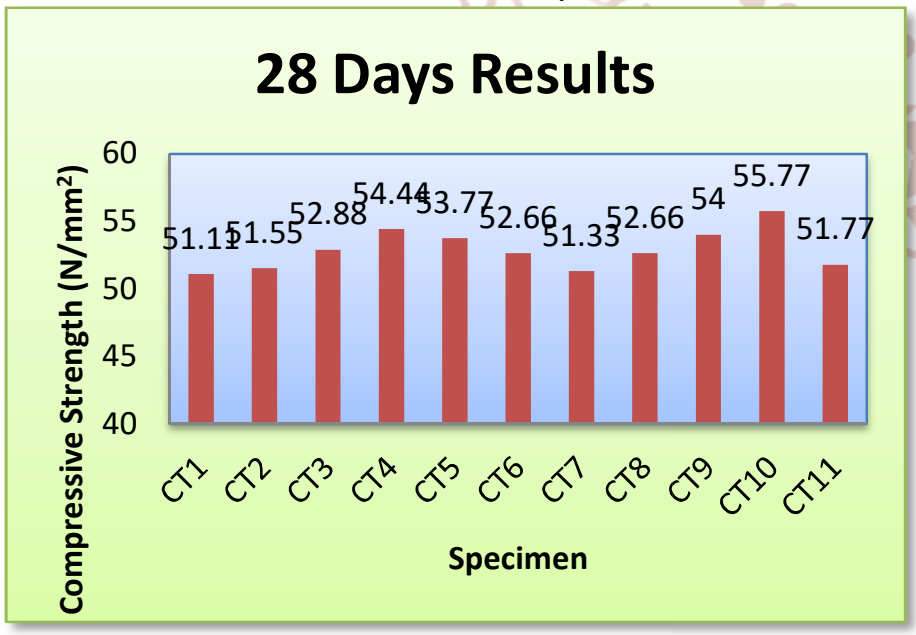

\subsubsection{Rebound Hammer Tests Results}

The same trend was observed in case in Rebound Hammer. The best results was in batch CT4 when $(6 \%)$ fibre is used as additive and CT10 when $(8 \%)$ fibre is used as a replacement of sand.
Table No. 4.4- Tests results of Rebound Hammer Test

\begin{tabular}{|c|c|c|c|}
\hline \multirow{2}{*}{ Cube } & \multicolumn{3}{|c|}{ Rebound Value } \\
\hline & 3 Days & 7 Days & 28 Days \\
\hline CT1 & 18.4 & 30.6 & 49.3 \\
\hline $\mathrm{CT} 2$ & 18.5 & 31.1 & 49.7 \\
\hline CT3 & 18.1 & 31.0 & 50.2 \\
\hline CT4 & 19.0 & 32.5 & 50.9 \\
\hline CT5 & 18.7 & 32.3 & 50.6 \\
\hline CT6 & 17.8 & 31.2 & 50.1 \\
\hline CT7 & 18.1 & 31.3 & 49.4 \\
\hline CT8 & 18.3 & 31.9 & 49.8 \\
\hline СТ9 & 19.6 & 32.4 & 50.2 \\
\hline CT10 & 19.7 & 33.5 & 50.0 \\
\hline CT11 & 19.1 & 32.4 & 49.6 \\
\hline
\end{tabular}

No.

Variation in results of rebound value of Cubes in 3 days.

\section{Days Results}

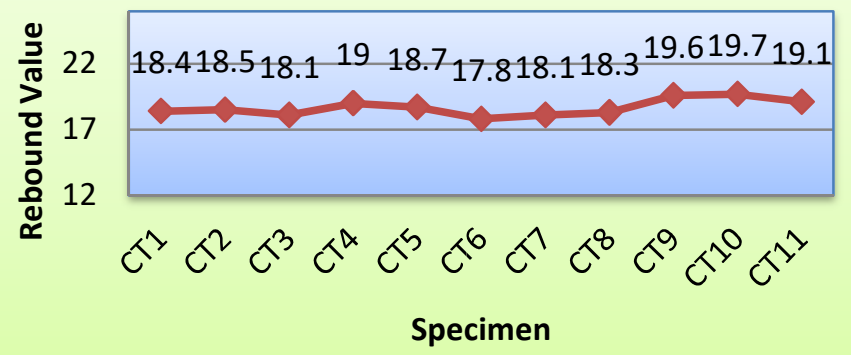

Graph No. 4.7-Variation in results of rebound value of Cubes in 7 days.

\section{Days Results}

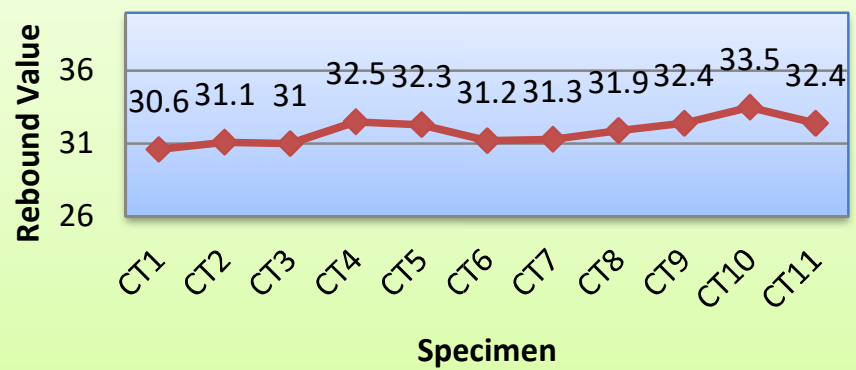

Specimen 
International Journal of Trend in Scientific Research and Development (IJTSRD) ISSN: 2456-6470

Graph No. 4.8- Variation in results of rebound value of Cubes in 28 days.

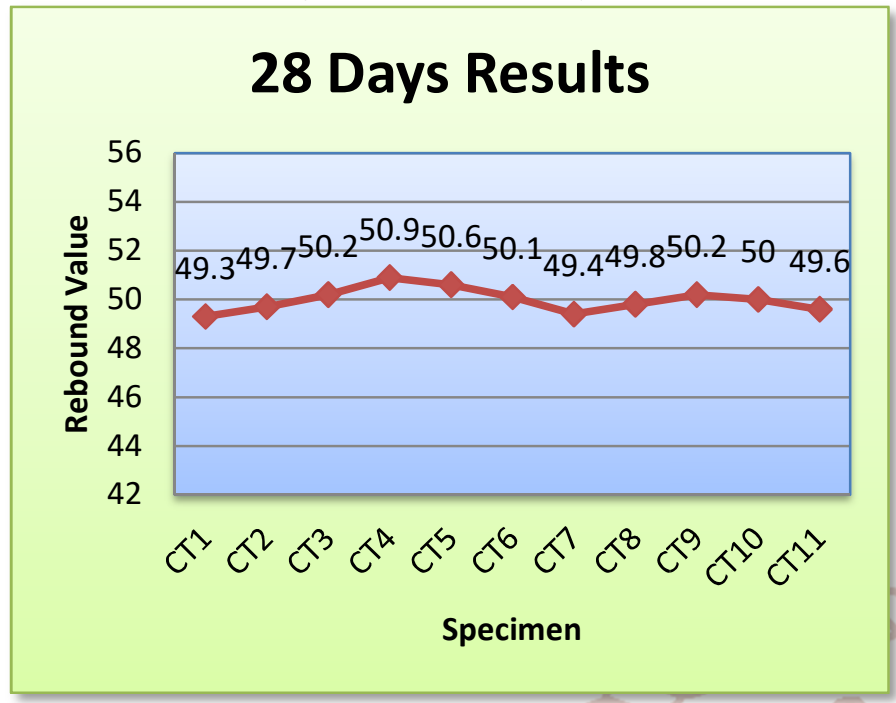

\subsubsection{Flexural Strength Test Results}

The Flexural strength of concrete was found in $\mathrm{N} / \mathrm{mm}^{2}$ at 7 and 28 days. It is tested on 6 different mixes. The mix design was selected from such previous concrete mix whose compressive strength was good in compression test in this project. The best results after 28 days was found in FS2 (6\%) as a additive fibre by weight of cement and in FS5 (8\%) as a replacement of sand, similar to the case of compressive strength.

Table No. 4.5- Tests Results of Flexural Strength Test.

\begin{tabular}{|c|c|c|}
\hline \multirow{2}{*}{ Beam } & \multicolumn{2}{|c|}{ Flexural Strength $\left(\mathrm{N} / \mathrm{mm}^{2}\right)$} \\
\cline { 2 - 3 } & 7 Days & 28 Days \\
\hline FS1 & 3.65 & 5.77 \\
\hline FS2 & 3.52 & 5.79 \\
\hline FS3 & 3.59 & 5.74 \\
\hline FS4 & 3.42 & 5.76 \\
\hline FS5 & 3.59 & 5.89 \\
\hline FS6 & 3.60 & 5.80 \\
\hline
\end{tabular}

Graph No. 4.9- Variation in Flexural Strength of Beams in 7 days.

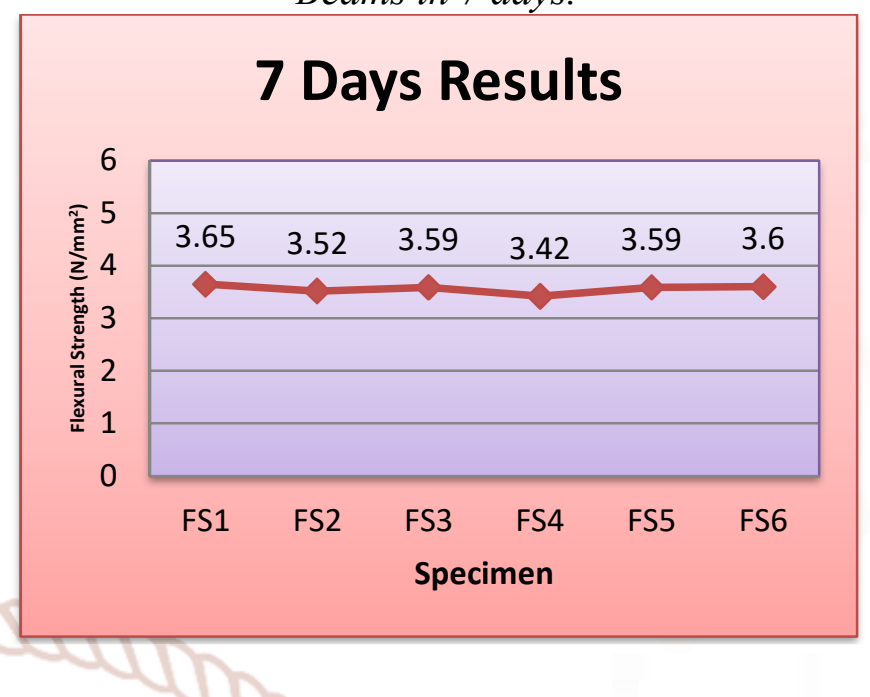

Graph No. 4.10-Variation in Flexural Strength of Beams in 28 days

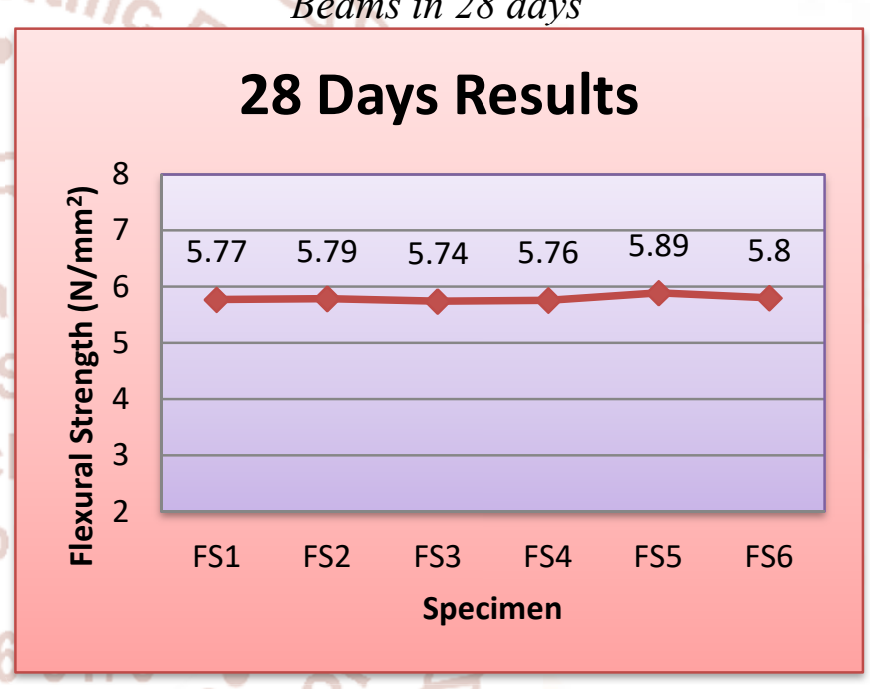

\section{COST ESTIMATION \& COMPARISON} 5.1 COST ESTIMATION

The cost estimation has been done separately in MS Excel for every mix proportions that being used in this project. The rate applied to the all the used materials to estimate cost is from current market price. Quantity estimation of all materials which are batched is done as per 1 cubic meter such that total quantity of each material can be calculated separately, and so on rates of each material as per market price are applied as per kilogram. Rate analysis shows that as the percentage of fiber increases, the cost goes on decreases. Reduction in $10 \%$ costs of fine aggregate can be achieved easily without affecting strength of concrete. 
International Journal of Trend in Scientific Research and Development (IJTSRD) ISSN: 2456-6470

Table No. 5.1-Quatity Estimate of Concrete $\left(\mathrm{kg} / \mathrm{m}^{3}\right)$.

\begin{tabular}{|c|c|c|c|c|c|c|}
\hline \multicolumn{2}{|c|}{ Batch Designation } & \multirow{2}{*}{$\begin{array}{l}\text { Fibre } \\
(\%)\end{array}$} & \multirow{2}{*}{$\begin{array}{c}\text { Cement } \\
\text { (kg.) }\end{array}$} & \multirow{2}{*}{$\begin{array}{l}\text { Sand } \\
\text { (kg.) }\end{array}$} & \multirow{2}{*}{$\begin{array}{l}\text { Aggregate } \\
\text { (kg.) }\end{array}$} & \multirow{2}{*}{$\begin{array}{l}\text { Fibre } \\
\text { (kg.) }\end{array}$} \\
\hline Title & Description & & & & & \\
\hline MD1 & Conventional & 0 & 450 & 664.24 & 1083.76 & 0 \\
\hline MD2 & \multirow[t]{5}{*}{ Fiber Reinforced } & 2 & 450 & 664.24 & 1083.76 & 9 \\
\hline MD3 & & 4 & 450 & 664.24 & 1083.76 & 18 \\
\hline MD4 & & 6 & 450 & 664.24 & 1083.76 & 27 \\
\hline MD5 & & 8 & 450 & 664.24 & 1083.76 & 36 \\
\hline MD6 & & 10 & 450 & 664.24 & 1083.76 & 45 \\
\hline MD7 & \multirow[t]{5}{*}{ Sand Replaced } & 2 & 450 & 650.95 & 1083.76 & 13.28 \\
\hline MD8 & & 4 & 450 & 637.67 & 1083.76 & 26.56 \\
\hline MD9 & & 6 & 450 & 624.38 & 1083.76 & 39.85 \\
\hline MD10 & & 8 & 450 & 611.10 & 1083.76 & 53.13 \\
\hline MD11 & & 10 & 450 & 597.81 & 1083.76 & 66.42 \\
\hline
\end{tabular}

Table No. 5.2- Cost of Materials.

\begin{tabular}{|c|c|c|}
\hline S. No. & Materials & Rate (Rs/kg.) \\
\hline 1 & Cement & 6.00 \\
\hline 2 & Sand & 0.60 \\
\hline 3 & Aggregates & 0.65 \\
\hline
\end{tabular}

Table No. 5.3- Cost Estimation of Concrete $\left(\mathrm{kg} / \mathrm{m}^{3}\right)$.

\begin{tabular}{|c|c|c|c|c|c|c|}
\hline \multicolumn{2}{|c|}{ Batch Designation } & Cement & Sand & Aggregate & Total Cost & \multirow[b]{2}{*}{ Change in Cost (Rs.) } \\
\hline Title & Description & (Rs.) & (Rs.) & (Rs.) & (Rs.) & \\
\hline MD1 & Conventional & 2700 & 398.54 & 704.44 & 3802.98 & Q \\
\hline MD2 & \multirow{5}{*}{ Fiber Reinforced } & 2700 & 398.54 & 704.44 & 3802.98 & 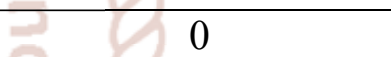 \\
\hline MD3 & & 2700 & 398.54 & 704.44 & 3802.98 & 0 \\
\hline MD4 & & 2700 & 398.54 & 704.44 & 3802.98 & $(8)$ \\
\hline MD5 & & 2700 & 398.54 & 704.44 & 3802.98 & 0 \\
\hline MD6 & & 2700 & 398.54 & 704.44 & 3802.98 & 0 \\
\hline MD7 & \multirow[t]{5}{*}{ Sand Replaced } & 2700 & 390.57 & 704.44 & 3795.01 & (-) 7.97 \\
\hline MD8 & & 2700 & 382.60 & 704.44 & 3787.04 & $(-) 15.94$ \\
\hline MD9 & & 2700 & 374.63 & 704.44 & 3779.07 & $(-) 23.91$ \\
\hline MD10 & & 2700 & 366.66 & 704.44 & 3771.10 & (-) 31.88 \\
\hline MD11 & & 2700 & 358.68 & 704.44 & 3763.13 & $(-) 39.85$ \\
\hline
\end{tabular}

Graph No 5.1- Variation in cost $\left(\mathrm{kg} / \mathrm{m}^{3}\right)$ with different mix

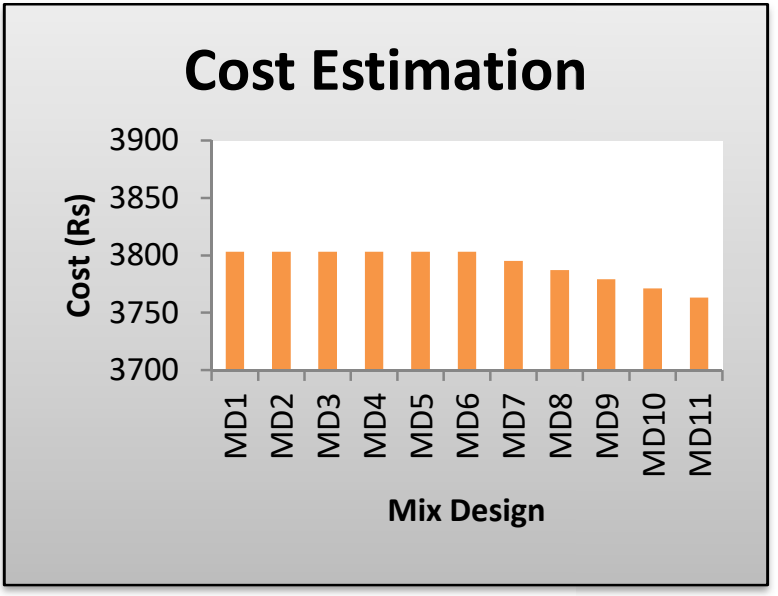

VI. CONCLUSIONS\&FUTURE SCOPE 6.1 CONCLUSION

1. A slump test results and compaction factor test results indicates with increase in fiber content, workability of mix decreases.

2. It has been found that fiber improves bond strength. Improvements in concrete properties of fresh concrete by the addition of fiber were observed.

3. Compressive and flexural strength increases with the increase in the percentage of fiber up to addition of $6 \%$ by weight of cement and $8 \%$ by replacement of sand.

4. The positive effects of the fibers become more significant after 28 days, but still it was 
capable to give concrete with better strength in early stages as compared to the plain concrete.

5. The use of fiber resulted in better elasticity of hardened concrete than conventional concrete without affecting the performance of concrete.

6. Replacement of fine aggregates also helped in achieving good compressive and flexural strength. Hence it is capable in reducing quantity of fine aggregates up to $10 \%$ without affecting the strength of the concrete.

\subsection{SCOPE FOR THE FUTURE WORK}

Further studies need to be conducted for the test of durability, soundness, thermal insulation, sorptivity and water absorption of the concrete.

1. Implementation of horse manure fibre in lower grades of concrete, which may be beneficial for such area where there is abundance of horse and its manure or where low cost housing is required.

2. Further studies need to be conducted by using hybrid fibers (combination of artificial and natural fibers) as reinforcement with steel fiber could increases tensile strength of concrete.

3. Experiments can be performed to study the behavior of soil reinforced with horse manure.

4. Horse manure is used as an alternative source in manufacturing of paper product in paper industry. As India is moving towards digitalization resulting in reduction in use of paper. So by using manure as a fiber will be beneficial trends for upcoming decades.

5. In some parts of world, horse manure is also used as a fuel for heat production in heating plant by combustion, further studies need to be conducted by testing properties of horse manure ash and if better results is achieved than it may be beneficial for replacement of cement by some percentage from horse manure ash for sustainable construction.

\section{REFERENCES}

1. A. KranthiSwarup, T. Naresh Kumar, Dr. N. VenkataRamana, "Comparative Study on Mechanical and Durability Properties of Concrete Using Fly Ash and Cow Dung Ash" International Journal of Research and Scientific Innovation (IJRSI) | Volume IV, Issue VIIS, July 2017 | ISSN 2321-2705.

2. Arun Kumar Jain, Ashok Kumar Jain and B.C. Punmia, "Reinforced Concrete Structures" Vol. 1, published by Laxmi Publications Pvt. Ltd, 1992.
3. B. N. Dutta and S. Dutta, "Estimating and Costing in Civil Engineering" $24^{\text {th }}$ revised edition, published by UBS Publishers Distributors, New Delhi, 1998.

4. Craig O. Thomas, Robert C. Thomas and Kenneth C. Hover, "Wastepaper Fibers in Cementitious Composites", Journal of Environmental Engineering, Vol. 113, Issue 1 February 1987, pp 16-21.

5. ElieAwwad, MounirMabsout, Bilal Hamad and HelmiKhatib, "Preliminary Studies on the use of Natural Fibre in Sustainable Concrete", Lebanese Science Journal, Vol. 12, No. 1, 2011, pp 109117.

6. EatherThanon,Dawood and MahyuddinRamli, "High Strength Characteristics of Cement Mortar Reinforced with Hybrid Fibres", Construction and Building Materials, Vol. 25, Issue 5, May 2011, pp 2240-2247.

7. Gonzalo Martinez Barrera, Enrique Vigueras Santiago, Miguel Martinez lopez, Maria C. S. Ribeiro, Antonio J. M. Ferreira and WitoldBrostod, "LuffaFibres and Gamma Radiation as Improvement tools of Polymer Concrete", Construction and Building Materials, Vol. 47, October 2013, pp 86-91.

8. H. Abdul Razak and T. Ferdiansyah, "Toughness Characteristics of ArengaPinnata Fibre Concrete", Journal of Natural Fibers, Vol. 2, Issue 2, 2005, pp 89-103.concrete.html

9. Hossam Hodhod and Mostafa A. M. Abdeen, "Simulation and Prediction for the Effect of Natural and Steel Fibres on the Performance of Concrete using Experimental Analysis and Artificial Neural Networks Numerical Modelling", KSCE Journal of Civil Engineering, Vol. 15, November 2011, Issue 8, pp 1373-1380.

10. H. Mohammad Hosseini and A.S.M. Abdul Awal, "Physical and Mechanical Properties of Concrete containing Fibres from Industrial Carpet Waste", International Journal of Research in Engineering and Technology, Vol. 02, Issue 12, December 2013, pp 464-468.

11. IS: 516-1959, "Method of Test for Concrete" Bureau of Indian Standards, New Delhi 1959.

12. IS: 1199-1959, "Method of sampling and analysis of Concrete" Bureau of Indian Standards, New Delhi 1959. 
13. IS: 2383-1963 (Part 1), "Methods of test of aggregate for concrete, Particles size and shape" Bureau of Indian Standards, New Delhi 1963.

14. IS: 2383-1963 (Part 3), "Methods of test of aggregate for concrete, specific gravity, density, voids, absorptions and buckling" Bureau of Indian Standards, New Delhi 1963.

15. IS: 383-1970, "Specification for coarse and fine aggregates from natural sources for concrete" Bureau of Indian Standards, New Delhi 1970.

16. IS: 12269-1987, "Specification for 53 grade ordinary Portland cement" Bureau of Indian Standards, New Delhi 1987.

17. IS: 9103-1999, "Specification for admixtures for concrete" Bureau of Indian Standards, New Delhi 1999.

18. IS: 7320-1974, "Specification for concrete slump test apparatus" Fourth Reprint November 2000.

19. IS: 456-2000, "For Plain and reinforced concrete, forth revision" Bureau of Indian Standards, New Delhi 2000.

20. IS: 10262-2009, "Recommended guidelines for concrete mix proportioning" Bureau of Indian Standards, New Delhi 2009.

21. JayeshkumarPitroda, L. B. Zala and F. S. Umrigar, "Innovative use of paper industry waste (hypo sludge) in design mix concrete", International Journal of Advanced Engineering Technology, Vol. 4, Issue 1, Jan-March 2013, pp 31-35.

http://www.academia.edu/34873234/Innovative_U se_of_Paper_Industry_Waste_Hypo_Sludge_in_P ervious_Concrete

22. J. H. Morton, T. Cooke and S. A. S. Akers, "Performance of Slash Pine Fibers in Fiber Cement Products", $10^{\text {th }}$ International Inorganic Bonded Fiber composite conference, November 15-18, 2006 Sao Paulo, Brazil, pp 168-177. https://www.infona.pl/resource/bwmeta1 .element. elsevier-f188031d-acd6-3cc2-b8f8-bb23de7cd280

23. J. Lundgren and E. Pettersson, "Combustion of Horse Manure for Heat production”, Bio Resource Technology, Vol. 100, Issue 12, June 2009, pp 3121-3126.

http://ri.divaportal.org/smash/record.jsf?pid=diva2 $\% 3$ A964831\&dswid=-7747
24. Jitender Kumar Dhaka, Surendra Roy, "Utilization of fly ash and cow dung ash as partial replacement of cement in concrete", International Journal of Civil and Structural Engineering Volume 6, No 1, 2015.

http://www.ipublishing.co.in/ijcserarticles/twelve/ lpages/0601/jcserlpvol6issue 1004.html

25. L. Lawrence, J. R. Bicudo and E. Wheeler, "Horse Manure Characteristic Literature and Database Review", Proceeding of the Ninth International Symposium Animal, Agricultural and Food processing Wastes IX. Raleigh, NC. ASAE, St. Joseph, MI., 2003, pp 277-284.

26. Matthias MönchTegeder, Andreas Lemmer, Hans Oechsner and Thomas Jungbluth, "Investigation of the Methane potential of Horse Manure", Agric Eng Int. CIGR Journal, Vol. 15, No.2, July 2013, pp161-172.

https://www.researchgate.net/profile/Thomas_Jun gbluth

27. N. Krishna Raju, "Prestressed Concrete", published by Tata McGraw-Hill Education, 2012.

28. N. Subramanian, "Design of Reinforced Concrete Structures" published by Oxford University Press, 16 Jan 2014.

29. O. Y. Ojedokun, A. A. Adeniran, S. B. Raheem and S. J. Aderinto, "Cow Dung Ash (CDA) as Partial Replacement of Cementing Material in the Production of Concrete", British Journal of Applied Science \& Technology 4(24): 3445-3454, 2014.

http://www.sciencedomain.org/abstract/5088

30. Pavithra. V, "an experimental investigation on concrete by using soil and cow dung ash as a partial replacement of fine aggregate and cement" International Conference on current Research in Engineering Science and Technology (ICCREST2016).

31. Pravin V Domke, "Improvement in Strength of Concrete by using Industrial and Agriculture Waste", IOSR Journal of Engineering, Vol. 2 (4), April 2012, pp 755-759. https://www.researchgate.net/publication/2520684 34_Improvement_In_The_Strength_Of_Concrete By_Using_Industrial_And_Agricultural_Waste

32. Ravindra K. Dhir, Trevor G. Jappy, "Exploiting Waste in Concrete", Proceedings of International Seminar, University of Dundee, Scotland, UK in 1999. 
https://books.google.co.in/books/about/Exploiting

Wastes_in_Concrete.html?id=ehbL6Z5-

8 AwC\&redir_esc $=y$

33. SiddiqueRafat, "Characteristics of Concrete Reinforced with San fibers", Research gate, Article: $\quad 1996$. http://shodhganga.inflibnet.ac.in/bitstream/10603/ 81676/21/21_references.pdf

34. S. K. Duggal, "Building Materials", fourth edition, published by New Age International (P) Limited, 2016. https://www.slideshare.net/katrinapradhan7/buildi ngmaterials3rdeditionby-skduggalpdf

35. Supriya Mishra, Amar K Mohanty, Lawrence T Drazal, Manjusri Mishra and Georg Hinrichsen, "A Review on Pineapple Leaf Fibres, Sisal Fibres and their Bio composites", Macromolecular Material and Engineering, Vol. 289, Issue 11, November 19, 2004, pp 955-974. https://onlinelibrary.wiley.com/doi/abs/10.1002/m ame. 200400132

36. Syed Mazharul Islam, Raja RizwanHussain, and Md. Abu ZakirMorshed, "Fiber Reinforced Concrete incorporating locally available Natural Fibers in Normal and High Strength Concrete and a performance analysis with Steel Fiber Reinforced Composite Concrete" Journal of Composite Materials, Vol. 46, 1, January 2012, pp 111-122. http://journals.sagepub.com/doi/abs/10.1177/0021 998311410492
37. S. O. R. CPWD-2015 for Rate Analysis. http://cpwd.gov.in/Documents/cpwd_publication.a spx

38. T. Omoniyi, S. Duna, A. Mohammed, "Compressive strength Characteristic of Cowdung ash blended cement Concrete" International Journal of Scientific \& Engineering Research, Volume 5, Issue 7, July-2014 ISSN 2229-5518. https://www.ijser.org/researchpaper/Compressivestrength-Characteristic-of-Cowdung-ash-blendedcement-Concrete.pdf

39. Thomas Dyer, "Concrete Durability" published by CRC Press, 01 May 2014. https://www.crcpress.com/ConcreteDurability/Dyer/p/book/9780415564755

40. V. Bhikshma, K. Nitturkar and Y. Venkatesham, "Investigation on Mechanical Properties of High Strength Silica Fume Concrete", Asian Journal of Civil Engineering (Building and Housing) Vol. 10, No. 3, 2009, pp 335-346. http://ajce.bhrc.ac.ir/Portals/25/PropertyAgent/290 5/Files/6151/335.pdf

41. Zhijian LiLijing Wang and Xungai Wang, "Compressive and Flexural properties of Hemp Fibre Reinforced Concrete", Journals of Fibers and Polymers, Vol. 5, Issue 3, September 2004,pp 187-197.

https://link.springer.com/article/10.1007/BF02902 998 